\title{
Ecsettoll, vagy ecset és toll? - Baromfi- és tojásábrázolás a festészetben egy állattenyésztő szemével
}

\author{
SÜTŐ ZOLTÁN \\ Kaposvári Egyetem, Agár- és Környezettudományi Kar, \\ 7400 Kaposvár, Guba Sándor u. 40., e-mail: suto.zoltan@ke.hu
}

\begin{abstract}
SüTö, Z.: Paintbrush or pen and brush? - Poultry and egg in fine art from an animal breeder's point of view.

Abstract: The various works of fine art can serve a number of interesting and uncompromising visual information from different eras when there are no other evidence to reconstruct a study event or to collide with various scientific hypotheses. This review introduces several examples when the poultry depicting of different periods mediates the natural science knowledge for the agricultural experts. For example, the first European artistic representation of turkey clearly demonstrates when the Spanish conquerors appeared in Central America, the domestication of wild turkey was already very advanced. It is very interesting that the representatives of poultry science did not think so before.
\end{abstract}

Keywords: paintings, Hungarian and international painters, history of poultry

„Boldogok a festők, mert ők soha nem lesznek magányosak: a fény és a színek, a béke és a remény kíséri el őket a nap vagy szinte a nap legvégéig."

(Winston Churchill ${ }^{1}$ )

\section{Bevezetés}

A világ legrégebbi nemzetközi baromfitenyésztési szervezetét tizennégy ország képviselői alapították 1912. július 18-án Londonban. Az 1916-ra tervezett 1. Baromfitenyésztési Világkongresszust a világháború kitörése miatt a szervezet csak 1921-ben Hágában tudta megrendezni. A ma már több, mint 100 éves múltra visszatekintő Baromfitenyésztők Tudományos Világszövetsége (World's Poultry Science Association) melynek mintegy 80 országból megközelítőleg 8000 tagja van, 1954 óta négyévente rendezi meg a szervezet legnagyobb szabású és legrangosabb eseményét, a világkongresszust. Az első ilyen alkalom, amelyiken személyesen is részt vettem 1992-ben Amszterdamban volt. Mondanom se kell, hogy a nyitó ceremónia eseménye felejthetetlen élményként ivódott belém, amikor az óriási színpadon a felgördülő függöny mögül Rembrandt: Éjjeli őrjárat című festményének élő képe nézett a delegátusokkal szembe (1. és 2. ábra).

Sir Winston Leonard Spencer-Churchill, brit politikus, az Egyesült Királyság miniszterelnöke 1940-45 és 1951-55 között. Tenyésztöként 1939-töl tagja az Öves Galloway Szarvasmarhatenyésztök Egyesületének (Belted Galloway Society), valamint a festészetben mutatott tehetsége alapján rendkívüli és tiszteletbeli tagja a Királyi Müvészeti Akadémiának (Royal Academy)
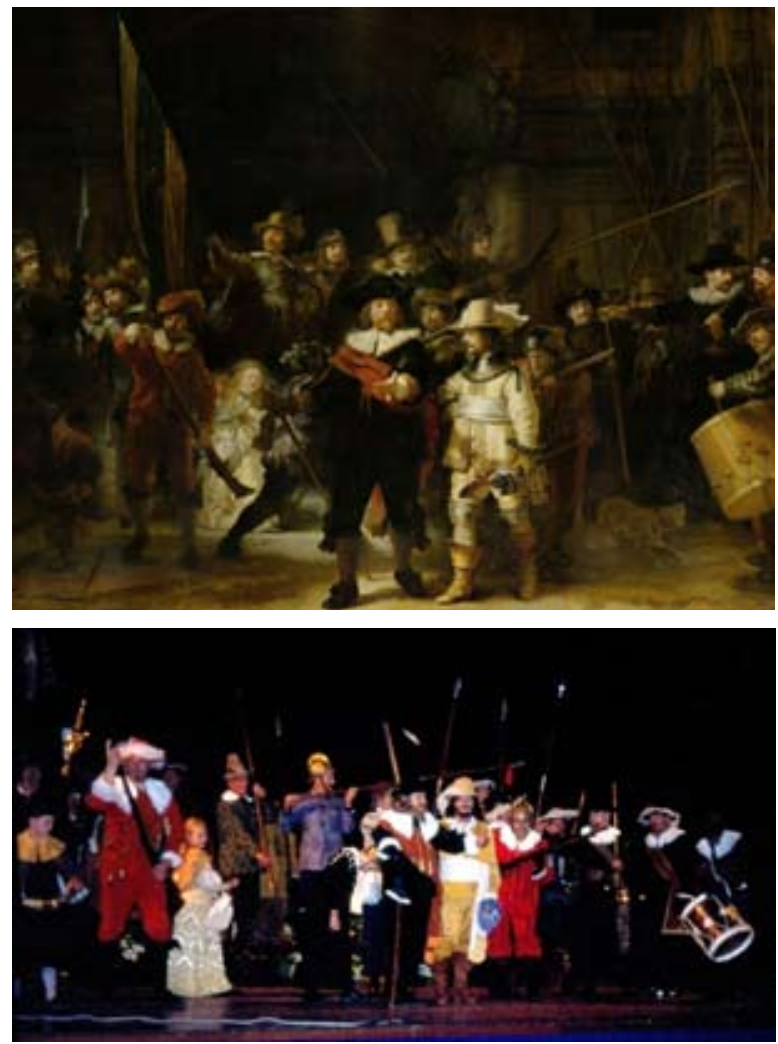

1. és 2. ábra. REMBRANDT HARMENSZ VAN RIJN (1606-1669): Éjjeli örjárat

(Rijksmuzeum, Amszterdam) - színpadkép

Miután Rembrandt eme leghíresebb müve is az amszterdami Rijks Múzeumban található, gondoltam, egy okkal több, hogy a kongresszus szabad programjának idejében magam is ellátogassak a híres képtárba. Nem volt könnyű betelni a németalföldi festészet itt kiállított számos remekével, de a lábam akkor gyökerezett földbe, amikor megpillantottam a holland festészet aranykorszakának legnagyszerübb csendéletei között Pieter Claesz: Csendélet pulykasülttel címü képét (3. ábra).

Természetesen lenyügözött a művész hallatlan finom ecsetkezelése, színes és dekoratív ábrázolásmódja, a fénnyel való játéka, és nagyon meghitt, szinte családias jellegű témaválasztása, de az igazi hatást a kép keletkezésének évszáma tette rám. Ugyanis a Pannon Agrártudományi Egyetemen tananyag gyanánt ekkor már használatos volt $A$ pulyka kultúrtörténete, tenyész- 


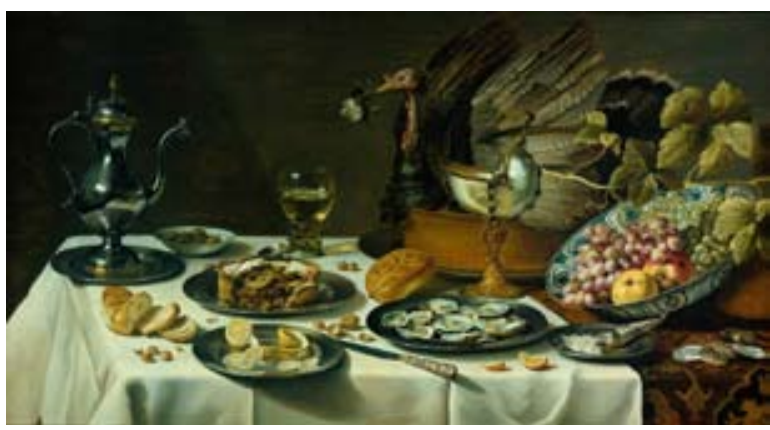

3. ábra. PIETER CLAESZ (c.1597-1660): Csendélet pulykasülttel (1627, Rijksmuseum, Amszterdam)

tése és tartása ${ }^{2}$ címü egységes egyetemi jegyzet, ami alapját képezte egy még nagyobb lélegzetvételü munkának $^{3}$, s ezen akkor már intenzíven dolgoztam. A festményt szinte bámulva, határozottan emlékeztem egy alig néhány éves, tehát viszonylag friss német szakirodalmi közlésre, amelyik azt írja, hogy „a hollandok csak a XVIII. század elején ismerték meg a pulykát'4. Az említett csendélet keletkezési idejét látva úgy gondoltam, hogy legkevesebb 100 évet még a szomszédnak sem illik tévednie. Az eset egyértelmüen a képzőmüvészet további bizonyítékai felé irányította a figyelmem, amikor az írott dokumentumok, vagy a Gutenberg-galaxis hiánya, esetleg utóbbi fogyatékosságai egy kérdés megítélésében nem tudnak segíteni ${ }^{5}$.

Ezt az elhatározást két további nagyon fontos impulzus is erősítette bennem. Az egyik, hogy Horn Artúr6 1955-ben megjelent Általános állattenyésztés című, korszakot meghatározó munkájának előszavában a következő olvasható: „Az általános állattenyésztéstan megírásával elsősorban tankönyvet kívántam adni hall-

2 Sütő Z. (1992): A pulyka kultúrtörténete, tenyésztése és tartása. Jegyzet, 1-161.p. PANNON Agrártudományi Egyetem, Állattenyésztési Kar, Kaposvár. (1995-ben elnyerte a Pro Agricultura Pannoniae Alapítvány Nívódíját)

3 Sütő Z. (1997): A pulyka. A Gazda és a Mezőgazda Kiadó közös kiadása, 1-180.p. Budapest.

4 Schmidt, H. (1989): Puten, Perlhühner, Gänse, Enten. Verlag: Neumann-Neudamm, Melsungen.

5 Szakmai szempontból azért annyit már itt is meg kell jegyezni, hogy a középkor föúri lakomáin nagy divat volt a kuriózumnak tekintett szárnyasok (pulyka, hattyú, daru, páva, stb.) elkészítésének és felszolgálásának különleges módja. Miközben Claesz csodálatos művének részletgazdagságában gyönyörködik a szemlélö, nem baj, ha tudjuk, hogy a festmény alapján miként is lehetett akkor a pulykasült tollas? A korszak fényüző pompájára jellemző volt, hogy a madártestet rendszerint megnyúzták - vagy a tollazatot megkímélve óvatosan távolították el - majd a konyhatechnikai elkészítés és sütés után a testet visszahelyezték a tollas bőrbe - vagy a tollak egy részét a bőrbe - azt az impozáns látszatot keltve, hogy az asztalnál lakmározó föurak tulajdonképpen a madár természetesen szép állapota alapján válasszanak a különleges csemegék közül, ami viszont ha úgy tetszik azonnal elfogyasztható (Gundel, 2013).

6 Horn Artúr (1911-2003) a Fasori Evangélikus Gimnázium növendéke, állami dijas akadémikus, tanszékvezető egyetemi tanár, dékán, az MTA rendes, továbbá a Német-, a Lengyel- és a Belga Tudományos Akadémia tiszteletbeli tagja, többszörös honoris causa doktor, az "Arany tojás" nemzetközi állattenyésztés-tudományi dij - a Distinguished Service Award - a METESZ-díj, valamint az Akadémiai Aranyérem birtokosa, a Munka Érdemrend arany fokozatának kitüntetettje, a magyar állattenyésztés-tudomány nemzetközileg elismert személyisége. gatóim kezébe, de olyan tankönyvet, amely a szorosan vett szakmai tudáson kívül állattenyésztési müveltséget is ad, hagyományainkról tájékoztat, állattenyésztés-biológiai látókört és szemléletet nyújt." A szavak súlya mellett az igazi bizonyítékot - a példát - a szakkönyv 64. oldalán találtam, ahol a magyar állattenyésztés nemzetközi hírü doenje Albrecht Dürer: $A$ tékozló fiú ${ }^{8}$ (rézmetszet) címü képét (4. ábra) használja annak illusztrálására, hogy 500 év alatt a vaddisznó kinézetü házi sertésből kiindulva, hova jutott el az állatnemesítés a XX. század közepére.

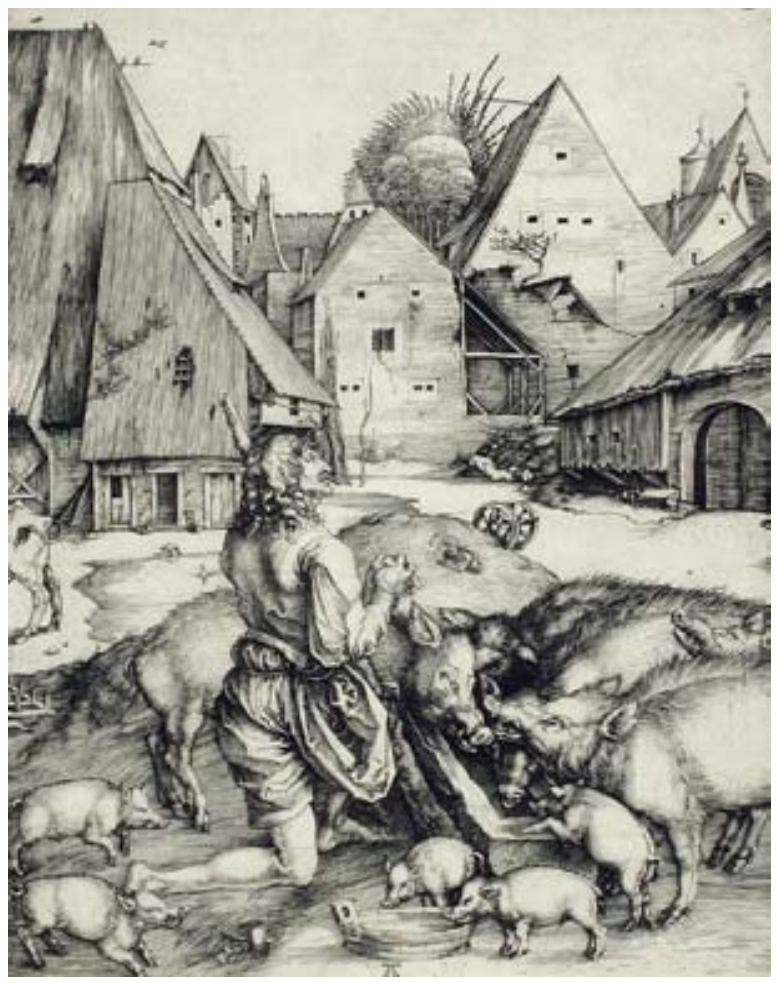

4. ábra. ALBRECHT DÜRER (1471-1528): A tékozló fiú (1520, rézmetszet, British Museum, London)

Pályám ezen időszakában több előadást hallottam azÁllatorvostudományi Egyetemen takarmányozástant oktató Fekete Sándor egyetemi tanártól, aki szebbnél szebb képzőművészi alkotásokkal illusztrálta és tette érdekessé először csak az előadásait, később pedig a keze alól kikerülő nívós szakkönyveket ${ }^{9}$ is. Tollat ragadva időnként magam is kardoskodok azért, hogy a szakács maradjon a fakanálnál, a suszter pedig a kaptafánál ${ }^{10}$. Éppen ezért, mint természettudományok-

7 Horn A. (1955): Általános állattenyésztés. (Agrártudományi Egyetem tankönyvei) Mezőgazdasági Kiadó, Budapest.

8 Egy bibliai példázatról van szó, amely Lukács evangéliumában található (Luk. 15:11-32, In: Szent Biblia (ford.: Károli G.) Magyar Bibliatársulat, 2001, Budapest.

9 Fekete S. Gy. (Ed.) (2008): Veterinary Nutrition and Dietetics. Pro Scientia Veterinaria Hungarica. Budapest, p. 1-1175. EUTextbook in English.

10 Sütő Z. (2013): Szakács a fakanálnál, cipész a kaptafánál ... Baromfi ágazat, 14. évf. (1) 1.p. 
kal foglalkozó szakember, nem kívánok Gerard Durrell analógiájára az amatőr 'művészetbúvár'11 keretein túl lépni és illetéktelenül garázdálkodni a képzőművészet, kiváltképp a festészet művészettörténeti útvesztőiben. Mindössze arról van szó, hogy a képzőművészet különböző alkotásai számos érdekes, nem egyszer perdöntő, vizuális információval tudnak szolgálni olyan korszakokról, amikor más bizonyítékok nem állnak rendelkezésünkre az események rekonstruálásához, vagy a különböző teóriák, tudományos hipotézisek ütköztetéséhez.

\section{Ecsettol, vagy ecset és toll}

Brillat-Savarin ${ }^{12}$ francia jogász, politikus és mesterszakács Az ízlés filozófiája címü, 1825-ben megjelent főművében azt írja: „A pulyka bizonyára egyike az Újvilág legszebb ajándékainak", amire akár Mark Twain ${ }^{13}$ kissé ironikus szavaival is válaszolhatunk: „Csodálatos, hogy fölfedezték Amerikát, de még csodálatosabb lett volna, ha nem fedezik föl." Tény, hogy a háziasított pulyka - és így a vadpulyka is - az amerikai kontinensről származik, tehát a madár európai ember általi megismerése a kontinens Kolumbusz általi felfedezésének egyik következménye. Történt, hogy 1520 körül Alexander Geraldini (c. 1455-1524) Santo Domingo (Haiti) püspöke - azaz Amerika első püspöke - ajándékba küldött egy pár pulykát Rómába. A címzett állítólag vagy a Raffaello által megfestett X. Leó pápa ${ }^{14}$ (5. ábra), vagy az ő pártfogoltja, az ugyancsak firenzei származású Lorenzo Pucci (1458-1531) bíboros volt. A feljegyzések tanúsága szerint a tojó fehér színű volt!

Igen, de milyen lehetett egy fehér színü pulyka a XVI. században? A fehér tollszín az egész testre kiterjedt, vagy csak bizonyos testtájon volt fehér a tollazat? És ha a madár tényleg fehér volt, akkor ennek milyen következményei vannak a pulyka háziasításáról vallott domesztikációs elméleteket illetően? Melyik kultúra európai, amerikai - mikor és mi módon háziasította meg a Közép- és Észak-Amerikában honos vadpulykát? Mondanom se kell, a kérdések megválaszolásában sokat segítene, ha csak egyetlen ilyen madarat láthatnánk! - Tegyük hozzá gyorsan - ha az előző fejezet végén írt vizsgálati módszer logikáját követjük akkor nem biztos, hogy ez ma lehetetlen.

Egyébiránt a pulyka első megjelenése Rómában akkora feltünést keltett, hogy 1522-23-ban a firenzei Giulio de 'Medici bíboros (a regnáló X. Leó pápa unokatestvére, a Raffaello festményen balra látható fiatal férfi, aki később VII. Kelemen néven pápa lesz) megbízta Giovanni da Udinet - Raffaello tanítványát - hogy

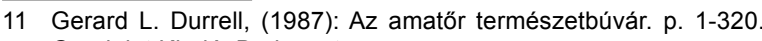
Gondolat Kiadó, Budapest.

12 Jean Anthelme Brillat-Savarin (1755-1826), francia jogász, politikus, mesterszakács, epikureista író. „Mondd meg mit eszel, s megmondom, ki vagy."

13 Mark Twain (1835-1910) amerikai író, újságíró, humorista.

14 X. Leó pápa, eredeti nevén: Giovanni di Lorenzo de' Medici (14751521).

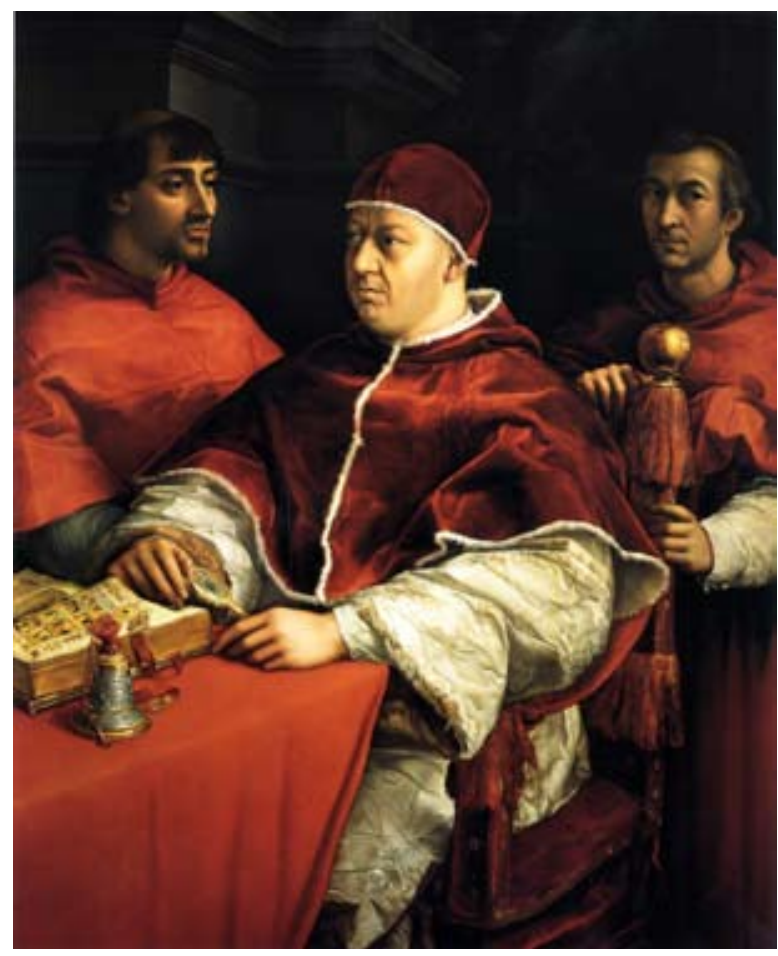

5. ábra. RAFFAELLO SANTI (1483-1520): X. Leó

(Medici) pápa (c.1518, Palazzo Pitti, Firenze)

római villájában - ez lett később a Villa Madama ${ }^{15}$ - a boltozathoz fessen antik áldozatokat bemutató képeket, struccot, pávát, kecskebakot és egy feltünően valóságos pulykát (6. ábra). Ez lett a pulyka első európai müvészi ábrázolása ${ }^{16}$ !

Az Udine által festett képről egyértelműen kiderül, hogy az oldalnézetben ábrázolt pulyka egy ivarérett, sátorozó kakas, aminek zsemle sárga színe még csak nem is emlékeztet a Közép- és Észak-Amerikában honos vadpulyka (Meleagris gallopavo, Linne,1758) egyetlen alfajának színére sem. Az első európai ábrázoláson szembetűnő, hogy a mell tájékon a kakas jelentős nagyságú - fonalas tollakból álló - mellpamacsot vagy szakállt visel, amit a baromfitenyésztők 'ecsettolnak' is neveznek. A dolgozat címében szereplő szójáték is ennek köszönheti születését, mert a pulykának a zoológiai leírások szerint ecsettolla (is) van, míg az ecsetet ragadó festőművészt sokszor a népes madárvilág tollai ejtik ámulatba, s így találkozik a vásznon az ecset és a toll.

15 A későbbi 'Villa Madama' Raffaello ritka és befejezetlen építészet alkotása. Madama nem más, mint Habsburg Margit, V. Károly német-római császár törvénytelen lánya, akinek Rómában palotája és villája is volt. A rezidencia jelenlegi tulajdonosa az olasz kormány, amit diplomáciai célokra, elsősorban magas rangú külföldi delegációk fogadására, nemzetközi egyezmények ratifikálásra használnak.

16 A madarak közül a strucc és a páva ösi szimbólumok a legendákban és a művészetben, de a pulyka abban a korban igazi újdonságnak számított, aminek nem volt semmilyen mélyebb oka, csupán azért került oda, mert olyan 'furcsán' nézett ki. Ez a pulykaábrázolás a Villa Madama nagy szalon melletti helyiségben a mennyezet alatt a legkorábbi ábrázolása a pulykának az egész európai művészetben. 


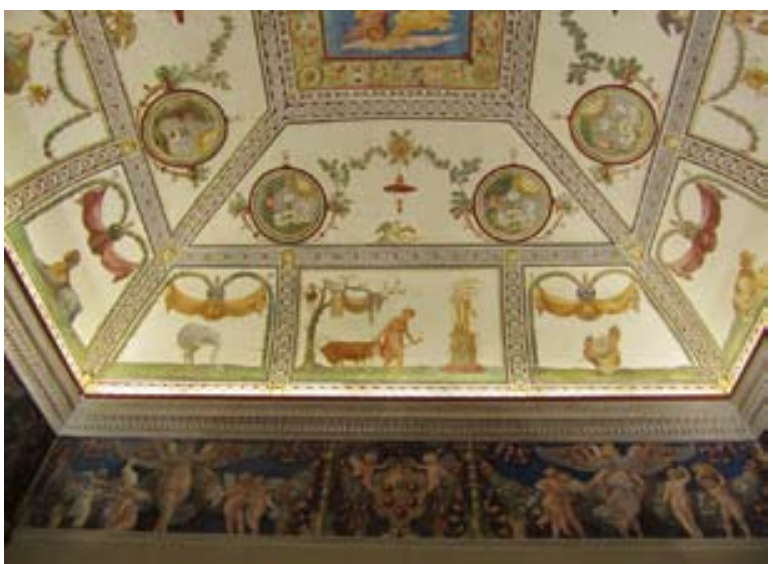

6. ábra. GIOVANNI DA UDINE (1487-1564): Áldozati állatok: strucc, kecskebak, pulyka, (1522-23, Villa Madama, Róma)

A téma nagyon szép illusztrációja látható a francia származású amerikai John James Audubon ${ }^{17}$ ornitológus és festő vadpulyka kakasról készült képén (7. ábra), ahol jól látható a vadászat alkalmával trófeának minősülő szakáll (beard). Ha a másik képen a néhány napos pipéket vezető tojót is alaposan szemügyre vesszük (8. ábra) a látvány és az összehasonlítás meggyőz bennünket, hogy Rómában Giovanni da Udine nem ilyen színű madarat látott és örökített meg a Medici villa, azaz a Villa Madama freskójaként.

Hogy az „unus testis, nullus testis” (=egy tanú, nem tanú) analógiájára ne kelljen bizonytalan teóriának hitelt adni, a különböző képtárakban szorgalmasan kutattam és szép számban találtam további bizonyítékokat a vad változattól lényegesen eltérő, nemesített, fehér illetve más színváltozatot, és ehhez még Itália földrajzi határait sem kell átlépni. A 9. ábra Francesco Bassano: Piac címü festménye, amely 1580/85 körül készült, és melynek jobb alsó negyedében galamb, lúd, kacsa, tojás és a pucolt baromfi mellett egy sötét színü - fekete - és egy határozottan elkülöníthető, fehér színű pulyka látható. Mindkettő kakas. A Bassano festő dinasztia annak a helységnek a nevét vette fel, ahonnét a család származott, és ami alig 65 kilométerre található Velencétöl. Attól a Velencétöl, ahol 1557-ben a Város Tanácsa - azaz a velencei patríciusok - a luxus megelözése céljából kiadtak egy rendeletet, ami törvénnyel szabályozta, hogy mikor és hol, milyen lakoma vagy ünnep alkalmával, kinek az asztalára szabad ünnepi ételként tálalni pulykahúst. S lám a különleges madarat alig két évtizeddel késöbb egy teljesen közönséges élethelyzetben látjuk, amikor mindenféle más egyéb élelmiszer társaságában egyszerüen árulják a piacon.

17 John James Audubon (1785-1851) természettudós, ornitológus és festő. Legismertebb müve a 'The Birds of America', amit elöször részenként publikált 1827 és 1839 között. Ez az egyik legjobb valaha készült madártani munka, aminek első kiadása Edinburghban és Londonban látott napvilágot. A kollekció 435 kézzel színezett, életnagyságú nyomatot tartalmaz, melyeket 497 madárfajról készített. Audubon egyébként 25 új fajt is azonosított. „A pulykák életmódjára vonatkozólag sok megfigyelésünk van, de egyik sem vetekszik azzal, amelyet Audubonnak köszönhetünk" - írta róla Brehm (1891).

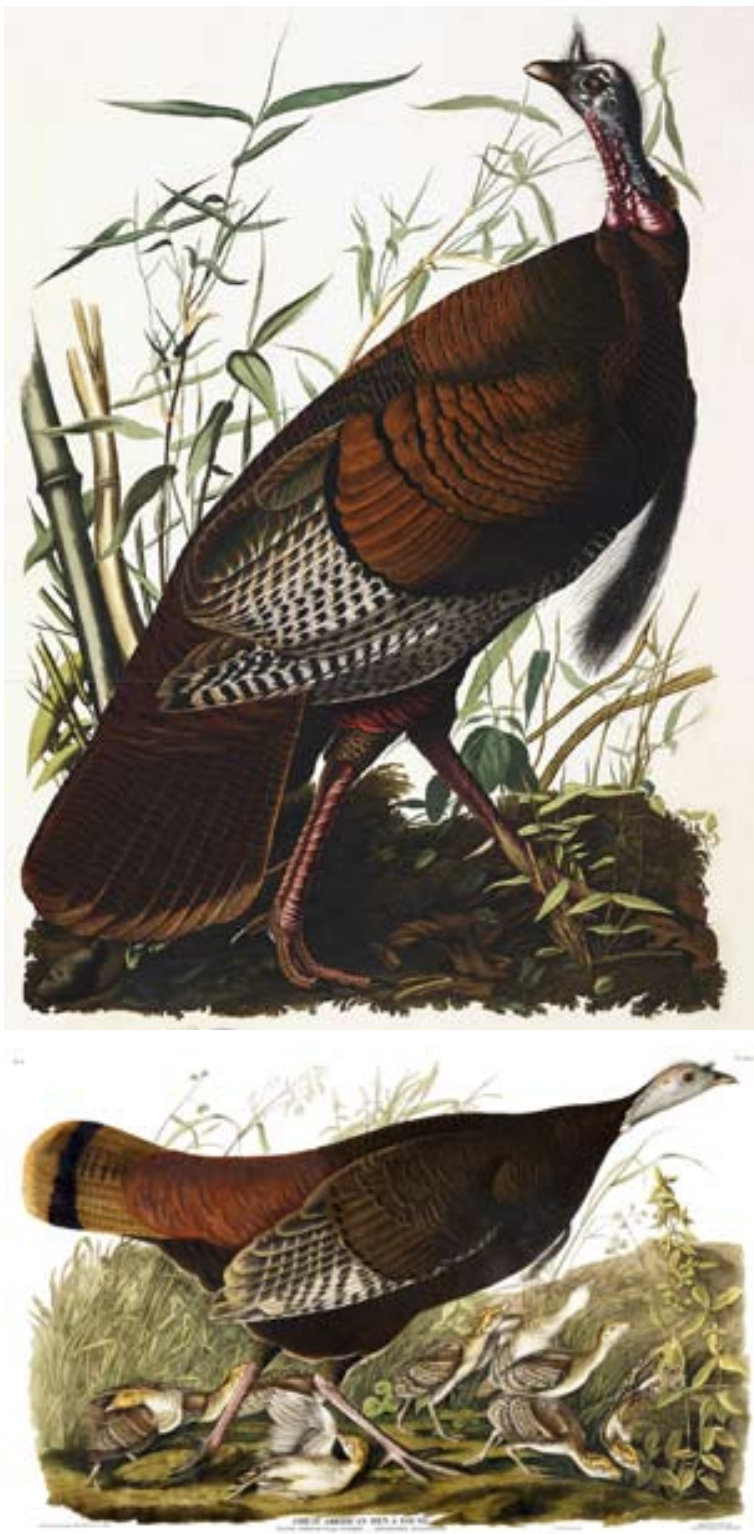

7. és 8. ábra. JOHN JAMES AUDUBON: Vadpulyka kakas, Pipéket vezetö vadpulyka tojó (1827-1839, The Birds of America)

Az új világból behozott pulyka fokozatosan elterjedt egész Európában, aminek számos bizonyítékát találjuk Franciaországban, a Németalföldön, de még Németországban is. A fehér tollszínü nemesített változat előfordulásának szép példája a német Christopher Paudiß: Pihenés útközben címü festménye (10. ábra), amire a müncheni régi képtárban akadtam. A festö egyébiránt Rembrandt tanítványa volt.

A látott példák egyértelmüen meggyőznek bennünket arról, hogy az új kontinenst felfedező konkvisztádorok valóban fehér színủ pulykákat (is) láttak és hoztak be Európába, ami egyértelmü bizonyítéka annak, hogy a spanyolok közép-amerikai megjelenésekor a pulyka háziasítása már igen elörehaladott állapotban kellett, hogy legyen, azaz jóval korábban megtörtént. 


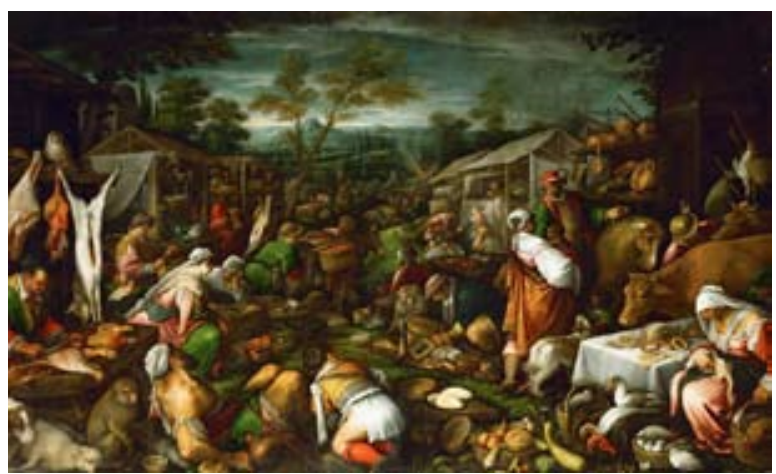

9. ábra. FRANCESCO BASSANO (1549-1592): Piac (1580/85, Kunsthistorisches Museum, Bécs)

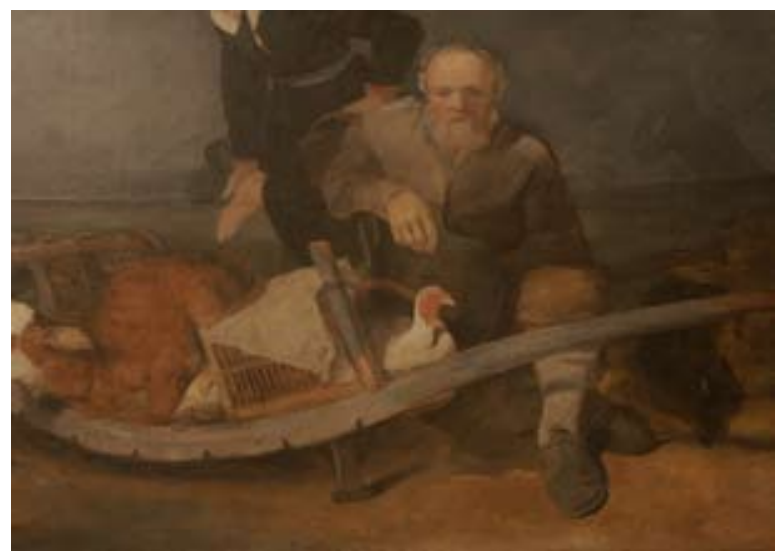

10. ábra. CHRISTOPHER PAUDIß (ca. 1625-1666):

Pihenés út közben (1630/66, Alte Pinakothek, München)

Ebből logikusan következik, hogy a faj domesztikációjához az európai kultúrák vajmi keveset tudtak csak hozzátenni. Az érdem inkább az aztékok, vagy a pueblo indiánok körében keresendő, de ebben a hallatlan érdekes egymásra találásban a pulykát, mint biológiai tényezőt sem szabad figyelmen kívül hagyni. Ezek a tapasztalatok egy speciális kérdésben engem arról győztek meg, hogy a képzőművészet - festészet, szobrászat ${ }^{18}$ - nagyon fontos segítséget, szinte mankót adhat a históriában összefüggéseket kereső kezébe, mert az állattenyésztés története elválaszthatatlan az emberi kultúra történetétöl, az pedig az események látványát megörökítő mủvészi ábrázolásoktól. 1992 után elindulva ezen az úton, magam sem gondoltam, hogy mára az 1. és a 2. táblázat lenyügöző névsora - de föleg a nevek mögött rejlö megannyi alkotás néz velem szembe. A táblázatok tartalmáról tudni kell, hogy a két lista valószínüleg soha nem lesz tökéletes.

18 A dolgozat témája és megközelítésmódja miatt, szobrászati alkotásokról nem esik szó, de ez nem jelenti azt, hogy ne tulajdonítanánk jelentőséget olyan müveknek, mint Giambologna nevéhez füződő, az 1560-as években bronzból készült $62 \mathrm{~cm}$ magas, első európai pulyka szobornak, ami a firenzei Bargello Múzeumban található.
Ezen a ponton a témában elhangzott korábbi előadásaim és az azok felhasználásával készített jelen dolgozat eljutott arra a pontra, hogy kénytelen szembesülni a saját naivitásával, mert a baromfi- és tojásábrázolás a festészetben méreteinél fogva még korlátozó tényezők mellett is alig feldolgozható, és a téma csak nagyfokú önkényességgel interpretálható, amit - hangsúlyozom - állattenyésztőként vállalok. Ennek során a szemem sarkában mindig ott lebegett Gombrich (1972) gondolata, aki azt mondta, hogy: „A müvészet valójában nem létezik, csak müvészek vannak. A müvészetről eleget tudni sohase fogunk, ha mégannyit tanulunk is."

\section{Mit lát egy állattenyésztő, ha beront a képtárba?}

Elsősorban a tyúkfélék ábrázolását kutattam, és kezdetben csak keresgéltem, hol véletlenszerüen, később aztán egyre szisztematikusabban, hol a valóságos, hol pedig a virtuális térben. Egy idő után határozottan éreztem, hogy valamilyen szempontrendszer szerint csoportosítani kell a fellelt alkotásokat. Miután sem prekoncepció, sem pedig müvészettörténeti béklyók nem kötötték meg a kezem, igyekeztem valamilyen rendszerbe elhelyezni a müveket. Két lehetőség azonnal kínálkozott. Az egyik szerint az emberiség írott kultúrtörténeti eseménysorára, azaz a Biblia ${ }^{19}$ történéseire füztem fel azokat a festményeket, amelyek képi megjelenítése - rendszerint mellékmotívumként - baromfit és/vagy tojást is ábrázol. Így született meg a következő, ha úgy tetszik tematizált fejezet, melyröl rövid áttekintést adok.

\section{Baromfiábrázolás a festészetben a téma kronoló- giája alapján}

Itt van mindjárt a 11. ábra - az egyik kedvencem melynek valóságos látványáért egész Rómáig mentem. Az osztrák származású Johann Wenzel Peter maga is hosszabb ideig élt az örök városban, ahol alkotása ma is méltó helyen található. A festmény - állítólag - több mint 200 fajt ábrázol, és zoológiai értelemben valamennyi tökéletes, ez ugyanis Wenzel ábrázolásának egyik nagy erőssége. A képről sugárzik az éden gondtalansága és derüs békéje. Ami részemröl a hangsúlyos megkülönböztetést illeti, azt azzal érdemelte ki, hogy 'a baromfi rendkívül közel van az első emberpárhoz'. A festmény fókuszában (12. ábra) egy impozáns pulykakakas sátorozik, de a szakértő szemnek nemcsak ez tünik fel, hanem a vörös színű kakas és a mellette élelmet csipegető fehér tyúk is. A látvány szakmai magyarázatához tudni kell, hogy egy angol kutató 1923-ban számolt be először az ivarhoz kötődő kvalitatív tulajdonságokról, és az ivart meghatározó jelenségröl a tyúkfajban. Magát az öröklésmenetet és annak keresztezéssel történő kihasználásának lehetőségeit csak 1928-ban fedezték fel és írták le először. A képen látható kakas genetikai értelemben egy recesszív arany homozigóta egyed $\left(Z^{s} Z^{s}\right)$, míg a tyúk az ivari kromoszómáján domináns ezüst tollszínt eredményező gént $\left(Z^{S} W^{-}\right)$hordoz, így a keresztezésükből olyan

19 Szent Biblia (ford.: Károli G.) Magyar Bibliatársulat, 2001, Budapest. 


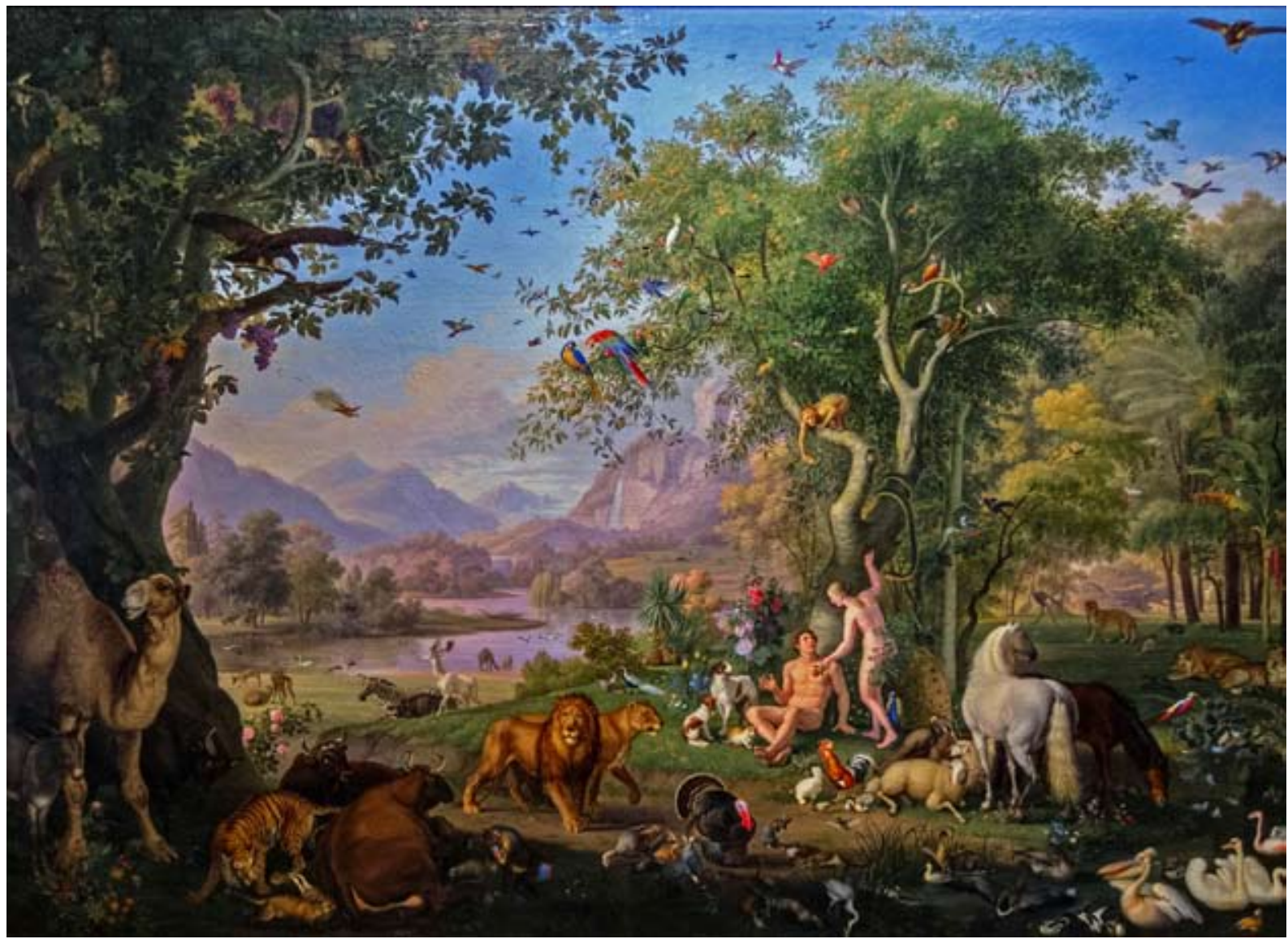

naposcsibék kelnek, melyek ivarát a színűk alapján már a kikelés pillanatában meg lehet állapítani. Nyílván ezt Wenzel nem tudta, ennek ellenére ő valami olyasmit ábrázolt, ami nélkül napjaink korszerü baromfitenyésztése

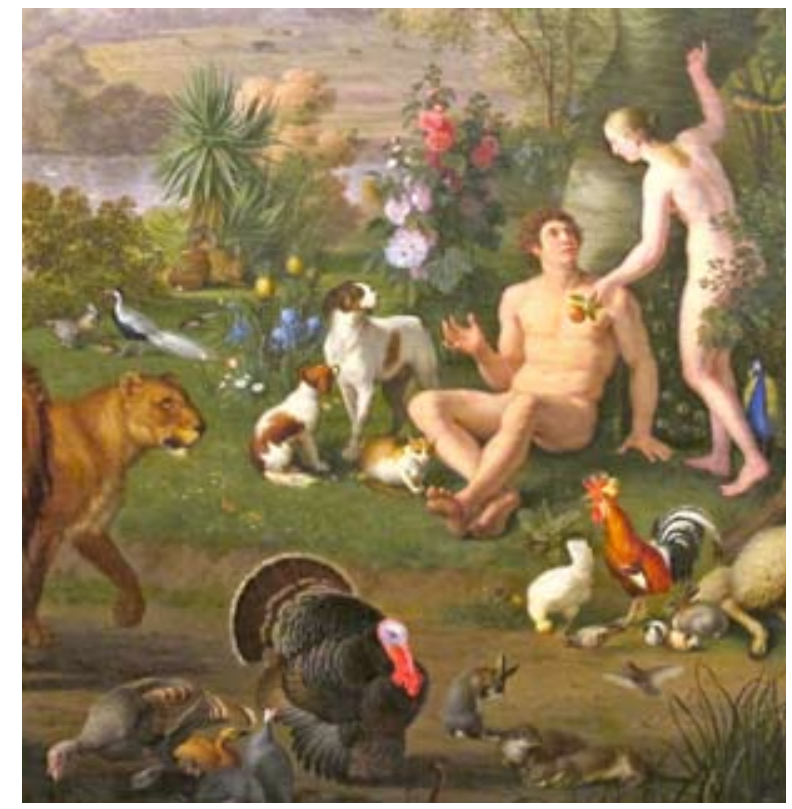

11. és 12. ábra. JOHANN WENZEL PETER (1745-1829): Ádám és Éva a Paradicsomban (1772, Vatikán Múzeum, Róma) - és részlet és mindennapi gyakorlata nem tudna létezni.

Egy közel 150 évvel korábbi mü, amiröl ugyancsak a Paradicsom idilli állapota sugárzik, és amely id. Jan Brueghel és Peter Paul Rubens közös alkotása (13. ábra). A szoros barátságot ápoló két művész közül a 'bársonyos Brueghel' becenév id. Pieter Bruegel második fiát, Jant illeti, aki méltó folytatója a család festő hagyományainak. A kép bal sarkában a mellét kidüllesztő melírozott tollú pulykakakas ékes bizonyítéka annak, hogy Európa nemcsak befogadta a kuriózumnak számító, különleges, pávaszerü, amerikai származású madarat, de tenyésztését - ami a faj színgazdagságát illeti - igen magas színvonalon múvelte is.

Az engedelmesség próbájának Ádám és Éva által elszenvedett kudarca az édeni idillt pillanatok alatt szertefoszlatta, és az első emberpárt Jacopo Bassano: Az Éden kertje címü képén (14. ábra) már meglehetősen komor környezetben ábrázolja. A képen látható állatok - kecskebak, juh, nyúl - szimbólumkénti megjelenítése minden bizonnyal nem véletlen, de érdekes, hogy ezek között egy jól megtermett kakas is helyet kapott, és ez sem ok nélküli.

Mikor, ha nem ebben az időszakban a bibliai témák igen népszerüek, akár az itáliai (Bassano, Tiziano), akár a flamand (Bloot, Bueckelaer, Brueghel, Vos), akár a 


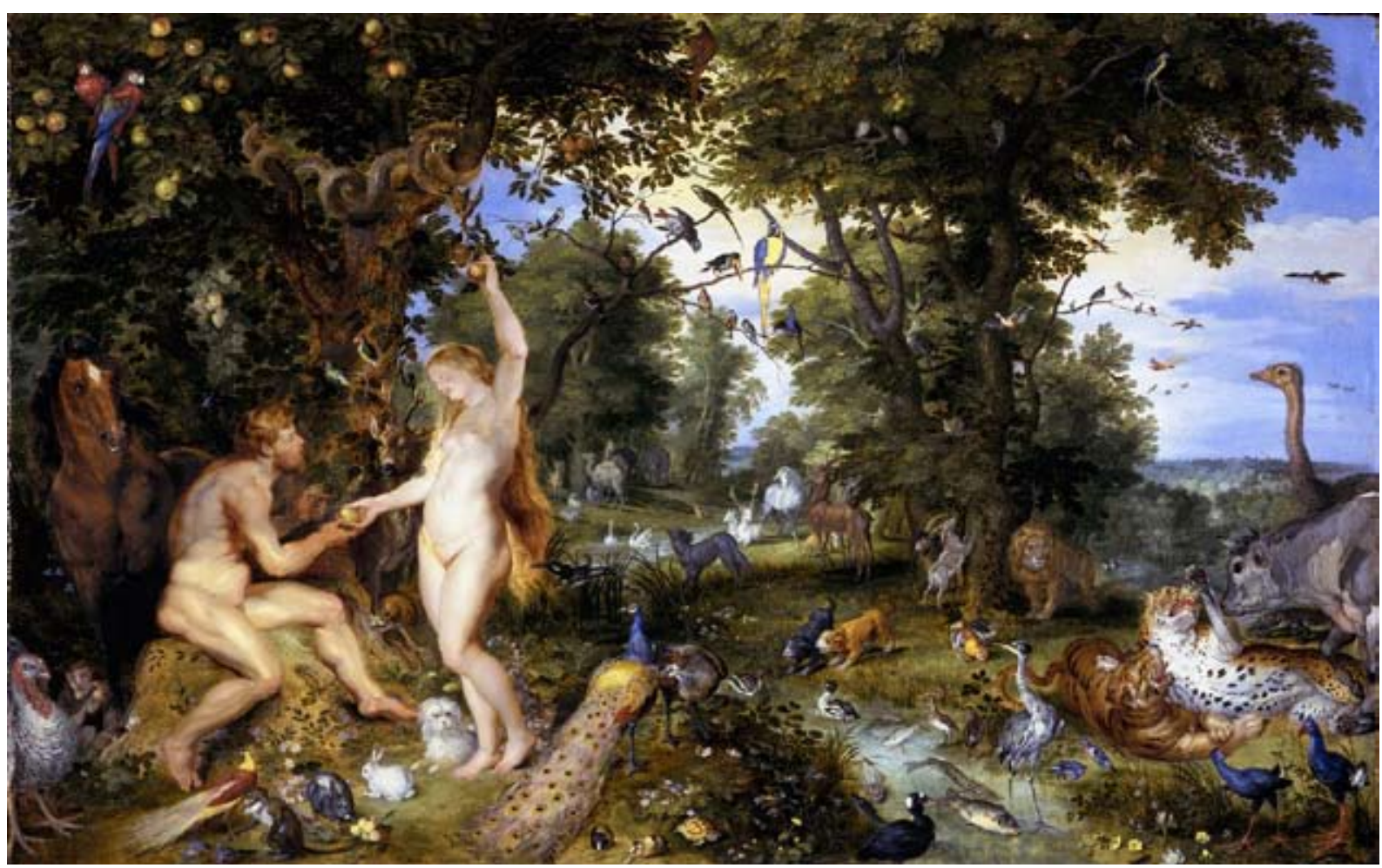

13. ábra. ID. JAN BRUEGHEL (1568-1625) és PETER PAUL RUBENS (1577-1670): Az éden kertje (1615, Mauritshuis, Hága)

spanyol (Velazquez), de még a francia (La Tour) festészetben is, tegyük gyorsan hozzá, azzal a megszorítással, hogy ezeknek az alkotásoknak van valamilyen baromfis vonatkozása. Az állatok be- és kimenetelének - Noé bárkájából - hihetetlen számú változata született, nem egyszer ugyanattól a müvésztől. Sok esetben baromfitenyésztési kavalkádot lát a szemlélő, de úgy, hogy az itáliai festészetben az esemény tragédiája üti szíven a nézőt (lásd: Bassano, 15. ábra), addig a flamand festészet ezt a pillanatot egy színes kirándulás tömegjeleneteként képes ábrázolni id. Jan Brueghel és Vos (16. és 17. ábra). Érdekes, hogy sem Noé hálaáldozata (18. ábra), sem pedig a zsidóság pusztai vándorlásának sorsfordító eseménye - mikor Mózes vizet fakaszt a sziklából (19. ábra) - nem nélkülözi a baromfi ábrázolását, aminek igenis jelentőséget kell tulajdonítanunk. Természetesen nem olyan értelemben, hogy ezek a fajok a történéseknek lettek volna fontos szerepelői, hanem jelentősek, azaz kitüntetettek voltak az ember számára akkor, amikor a művész saját korának berendezkedése, jellegzetessége, értékrendje szerint vászonra vitte a történelmi eseményt.

Érdekes, hogy az oly sok művész által és oly gyakran ábrázolt esemény, mint Jézus születése, az állatseregletben a legritkább esetben vonultat fel baromfit. A dolog logikus, hisz a nyájat őrző pásztorok juhot, kecskét, szarvasmarhát, és legfeljebb teherhordásra használatos szamarat tartottak a pusztában, mit keresett volna ott baromfi? Az istálló padlásán látható kakas (20. ábra, ismeretlen cseh mester alkotása) akár prekoncepciónak is tekinthető, mint kellék gyanánt az a színpadi revolver, amit azért látunk az első felvonásban, hogy a darab későbbi részében biztosan eldördüljön. Ugyanakkor a baromfi/tojás az események valóságos idejében is ott lehetett (21. ábra) - mi több, meghatározó volt a szerepe - de ezek szerint a művész korának is fontos részese kellett, hogy legyen. Előbbi tételt igazolja az alábbi bibliai idézet, amiből kitünik, hogy a tojás, illetve a tojásfogyasztás már akkor nagyon pozitív tartalmat hordozott: „Melyik atya pedig az közületek, akitöl a fia kenyeret kér, és ő talán követ ád néki? Vagy ha halat, vajon a hal helyett kígyót ád-é néki? Avagy ha tojást kér, vajon skorpiót ád-é néki?" (Luk. 11,12). És lám, mind a spanyol Velázquez (22. ábra), mind pedig a flamand Bloot (23. ábra), ugyanannak a bibliai jelenetnek kellékévé teszi a tojást, mint a kezdet és az újjászületés szimbólumát, nyilván nem véletlenül.

Egyébiránt ha a baromfit keressük a Bibliában, egy rendkívül szemléletes hasonlat mellett biztosan nem mehetünk el szó nélkül, ráadásul ezt a fájdalmas mondatot nem is akárki, hanem egyenesen Jézus mondta: „Jeruzsálem, Jeruzsálem! Ki megölöd a prófétákat, és megkövezed azokat, akik te hozzád küldettek, hányszor akartam egybegyüjteni a te fiaidat, miképpen a tyúk egybegyüjti kis csirkéit szárnya alá; és te nem akartad." (Mt. 23:37, Luk. 13:34) Aki látott már életében kotlóst tojásokon ülni, majd amikor a fészekalja csibét vezetgeti és tanítgatja a tyúk, az tökéletesen megérti ennek a szándéknak, ennek az önfeláldozó magatartásnak a lényegét. A magyar állatábrázolás ide 


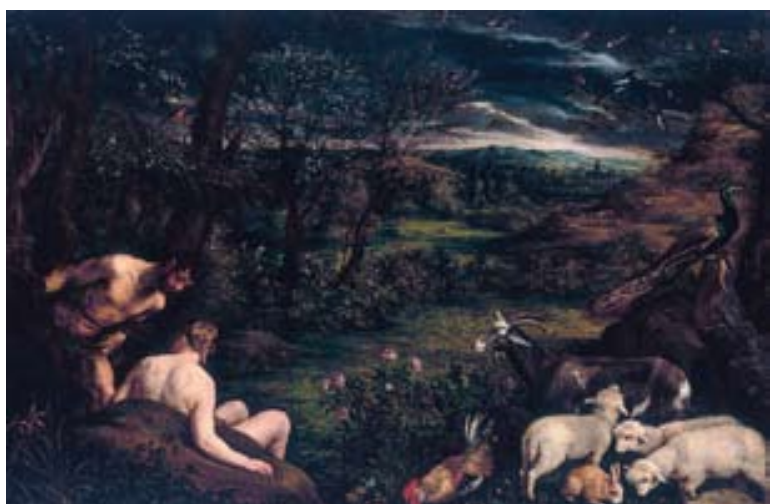

14. ábra. JACOPO BASSANO (c.1515-1592): Az Éden kertje

(1570-73, Galleria Doria-Pamphili, Róma)

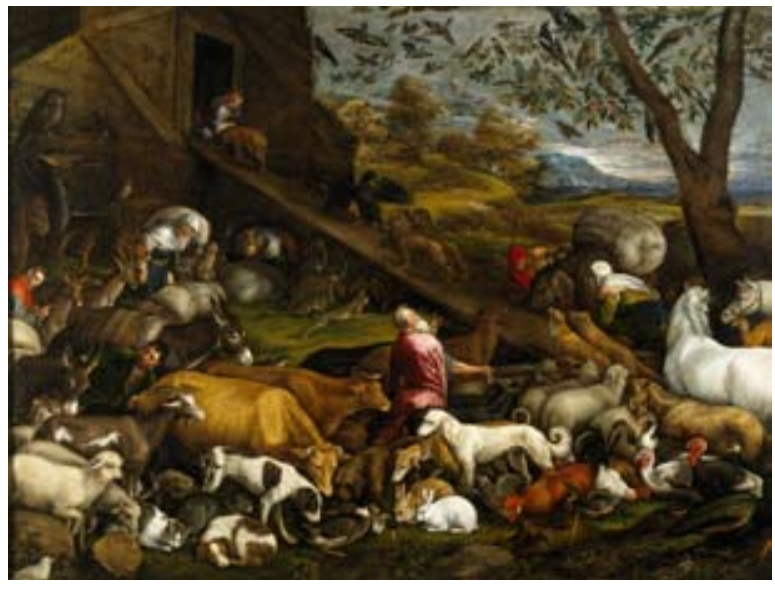

15. ábra. JACOPO BASSANO (c.1515-1592): $A z$ állatok bebocsátása Noé bárkájába (c. 1570, Museo del Prado, Madrid)

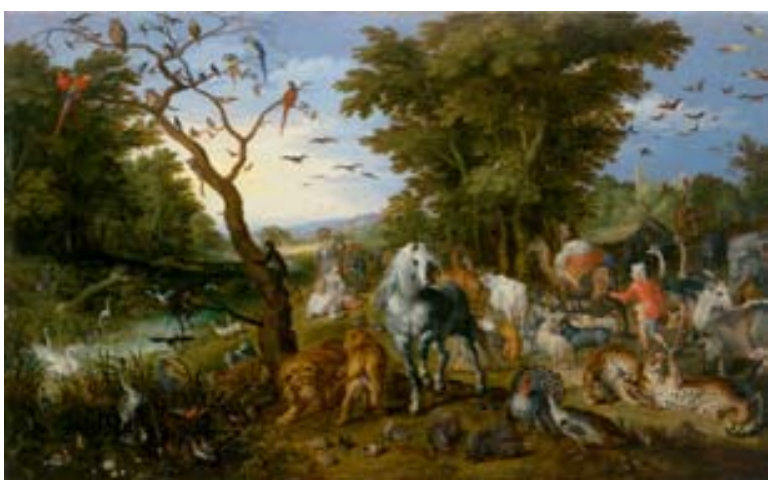

16. ábra. ID. JAN BRUGHEL (1568-1625):

Az állatok bemenetele Noé bárkájába (1613 The Getty Center, Los Angeles, USA)

válogatott két remekmüvének alkotója (24 és 25. ábra) csodálatosan látta meg és vitte fel vászonra az anyai magatartás talán legérzékletesebb megnyilvánulását, amikor a tyúk megmutatja az őt körülvevő világnak, hogy mi a legszebb, a legnemesebb feladat, és ezt valami végtelen türelemmel és alázattal csinálja.

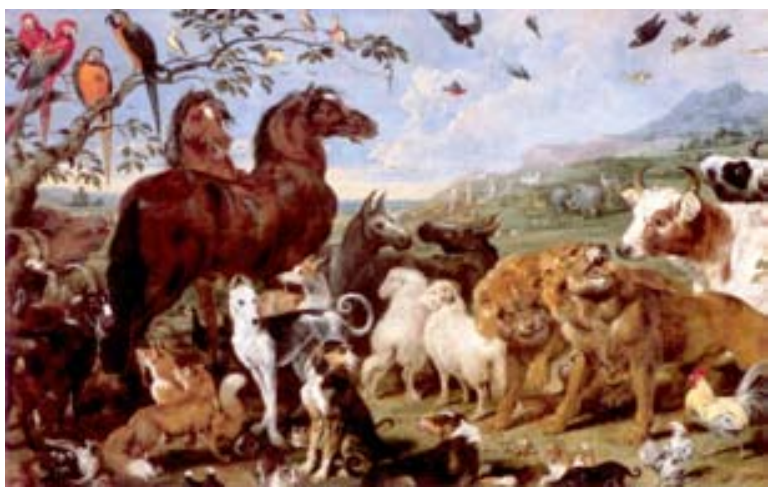

17. ábra. PAUL DE VOS (c.1596-1678):

Az állatok elhagyják Noé bárkáját (Louvre, Párizs)

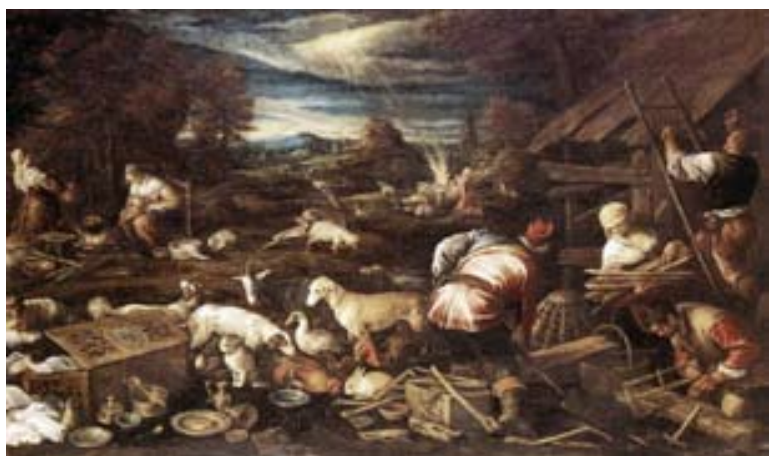

18. ábra. JACOPO BASSANO (c.1515-1592): Noé hálaáldozata (c. 1574, Staatliche Schlösser und Gärten, Potsdam-Sanssouci)

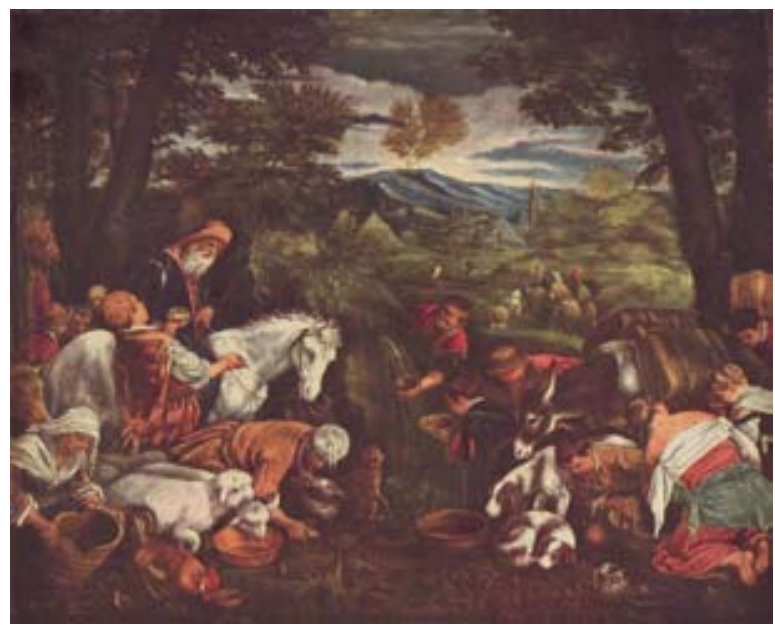

19. ábra. LEONARDO BASSANO (1557-1622):

Mózes vizet fakaszt a sziklából (Louvre, Párizs)

Érdekes, hogy a Biblia egyik döntő fontosságú katarzisa - emberi gyengeségünk mementója - ugyancsak nem nélkülözi a baromfit (26. ábra). „És hátra fordulván az Úr, tekinte Péterre. És megemlékezék Péter az Úr szaváról, amint néki mondta: Mielőtt a kakas szól, háromszor megtagadsz engem. És kimenvén Péter, 


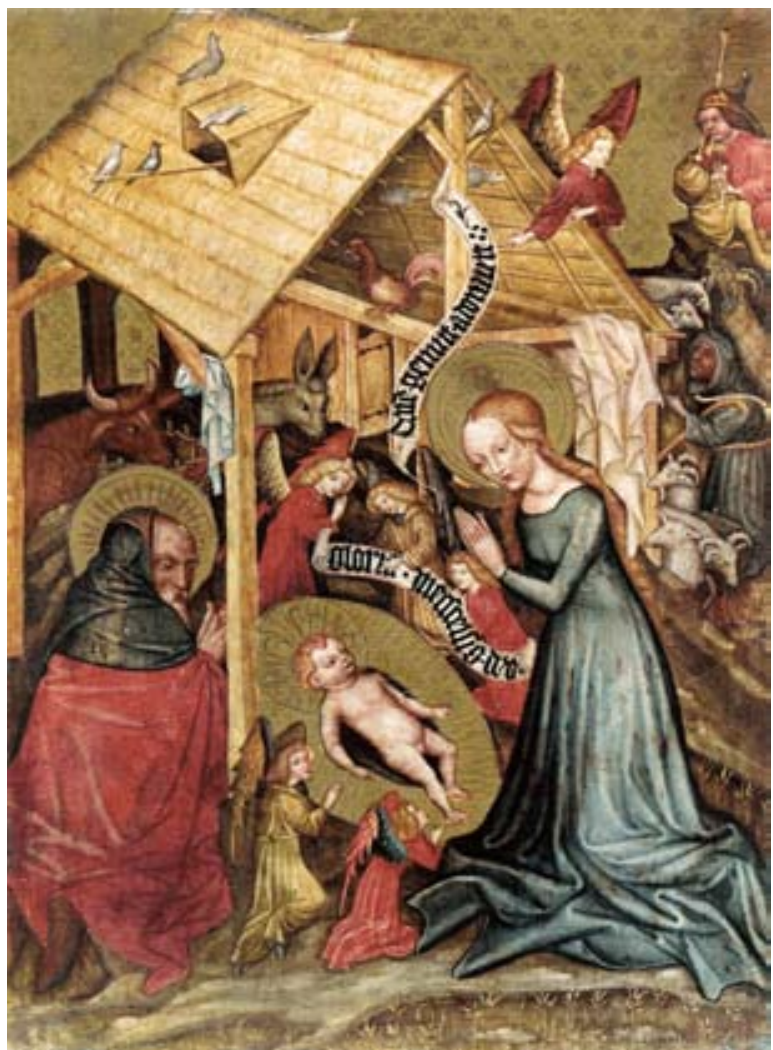

20. ábra. AN. (Ismeretlen cseh mester, 1430): Jézus születése

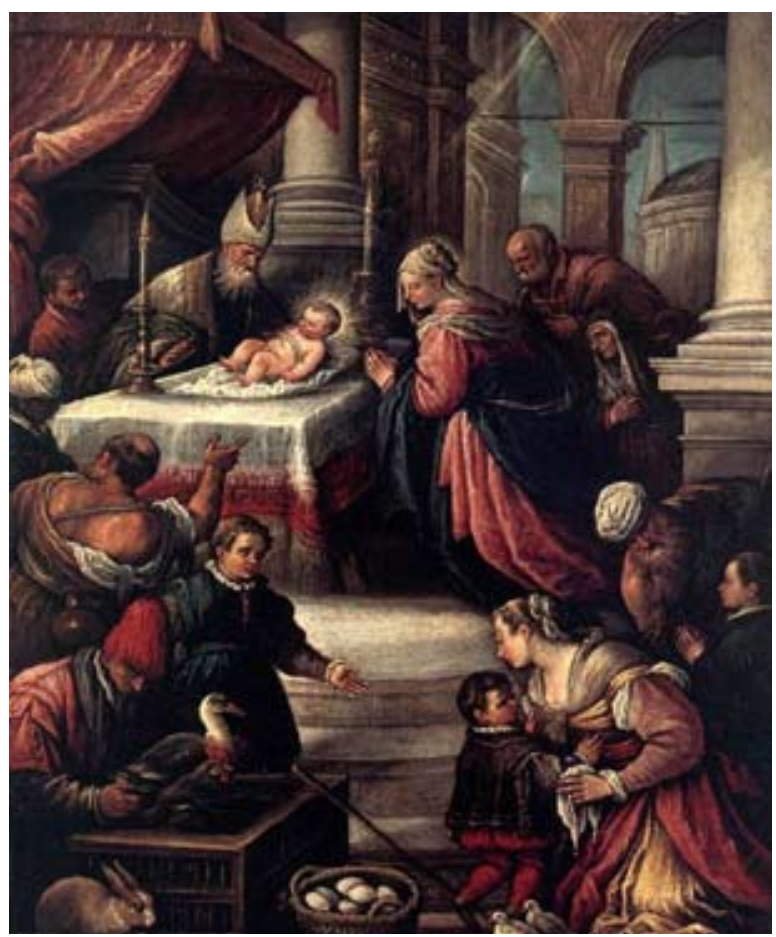

21. ábra. FRANCESCO BASSANO (1549-1592): Jézus bemutatása a templomban

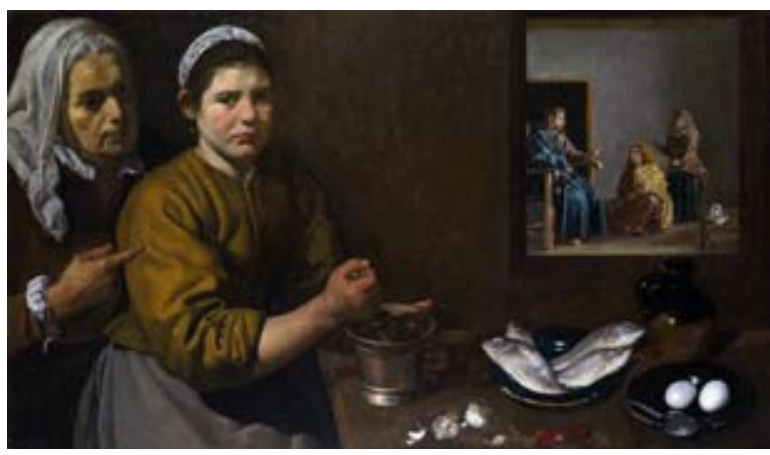

22. ábra. DIEGO VELÁZQUEZ (1599-1660): Krisztus Márta és Mária házában (1618)

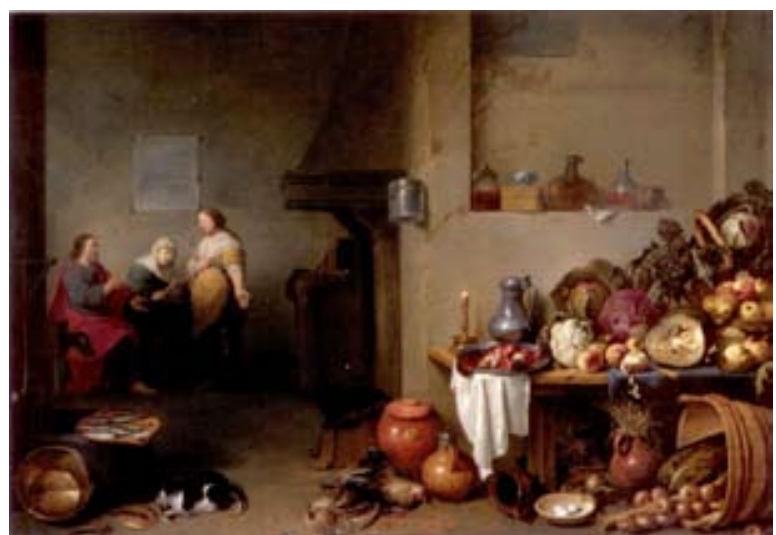

23. ábra. PIETER DE BLOOT (1601-1658): Krisztus Mártával és Máriával (1637, Liechtenstein Museum)

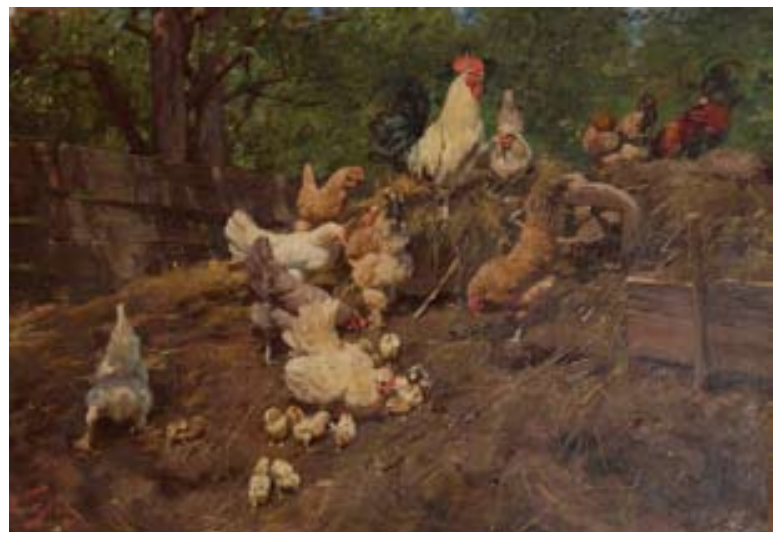

24. ábra. VASTAGH GÉZA (1866-1919):

Baromfiudvar (Magyar Mezőgazdasági Múzeum, Budapest) 


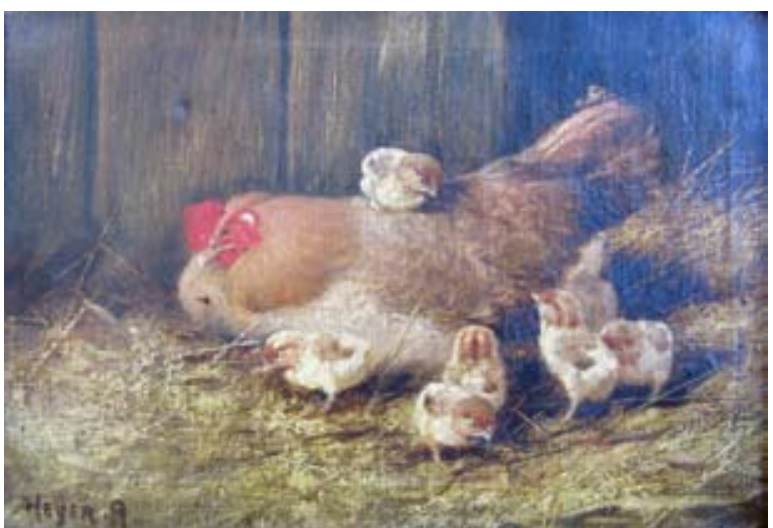

25. ábra. HEYER ARTÚR (1872-1931):

Kotlós a csibékkel (Magángyüjteményben)

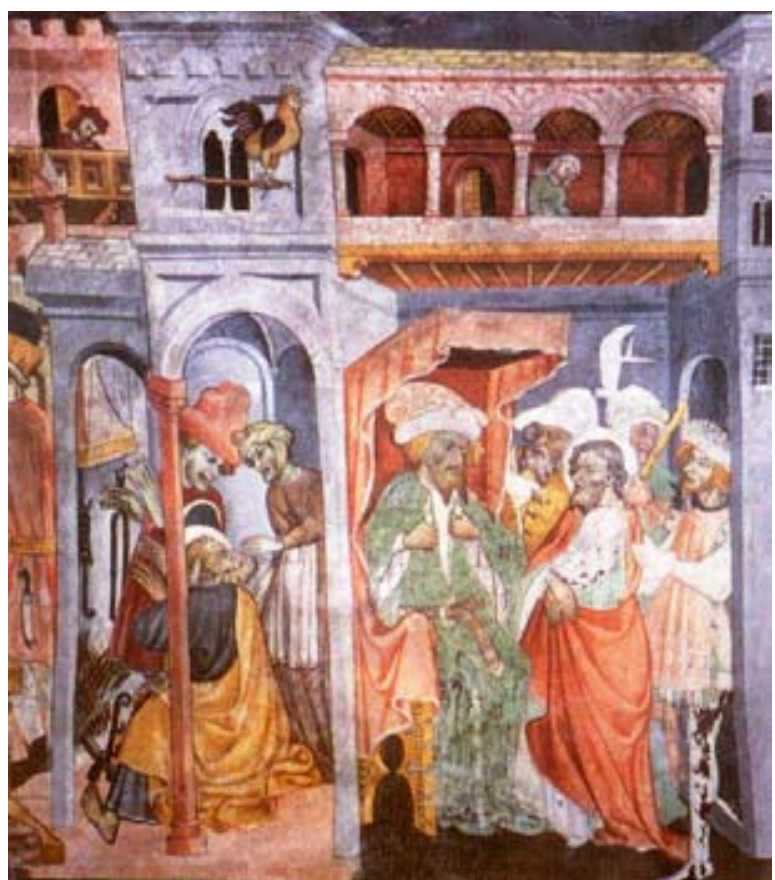

26. ábra. GIACOMO JAQUERIO (c.1375-1453) Péter háromszor tagadja meg Krisztust (XV. századi freskó)

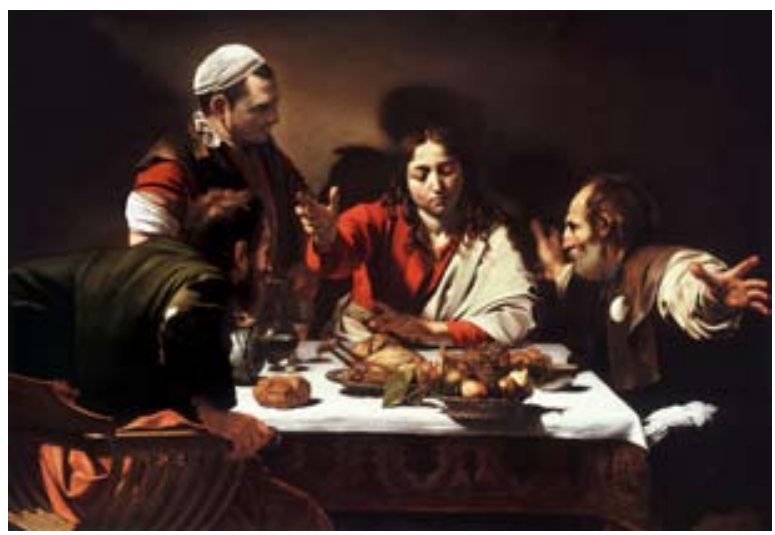

27. ábra. Caravaggio (Michelangelo Merisi, 1571-1610): Az emmausi vacsora (1601-02) keservesen síra." (Luk. 22:61-62, Mt. 26:34-35, Mk. 14:29-30) Noha Jeruzsálemben, Kajafás háza előtt az eseményre még szoborkompozíció is emlékeztet ${ }^{20}$, a festőművészek nem igazán kényeztették el az utókort jelentős számú alkotással, megörökítve azt a bizonyos péntek hajnali pillanatot. Egy biztos! Jeruzsálemben akkor volt kakas, és azt is tudta, hogy mi a dolga.

Aztán a XVI. század itáliai müvészetében jött egy nyughatatlan fiatalember, akinek festészetét forradalmian új stílus jellemezte, amely a fény és árnyék kontrasztján alapult. Caravaggio ${ }^{21}$ ellenezte a bibliai témák hagyományos, eszményített értelmezését, és modelljeit az utcáról szerezte, a vallásos jeleneteket életszerüen festette meg. Mesterművei között ott található $A z$ emmausi vacsora. A festmény (27. ábra) érdekessége az, hogy a történésekben fontos szerepet játszó kenyér mellett egy termetes - mai szóhasználattal élve - grillcsirke is van asztalon, miközben az alkotás mindazoknak a sajátosságoknak a tipikus hordozója, ami Caravaggio látásmódjára igazán jellemző. Nem sokkal később ezt a bibliai jelenetet a művész újra megfestette, de min mehetett át Caravaggio időközben, amitöl eltűntek a harsogó színek, megváltozott a pirospozsgás Jézus, és természetesen nyoma sincs az asztalon a sült csirkének (28. ábra).

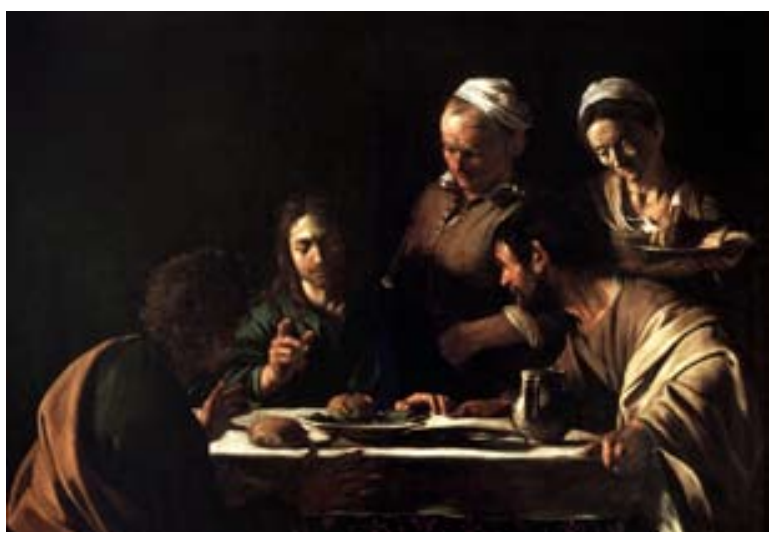

28. ábra. CARAVAGGIO (Michelangelo Merisi, 15711610): Az emmausi vacsora (1606, Pinacoteca di Brera, Milánó)

\section{Baromfiábrázolás a magyar festészetben - somo- gyi müvészek}

A baromfit, illetve tojást ábrázoló festmények csoportosításának másik lehetséges módja, hogy az alkotásokat a megszületés kronológiája alapján állítjuk sorba, vagy a művész nemzetisége, vagy földrajzi kötődése alapján különítjük el. Egy biztos, hogy ebben az esetben sokkal több olyan alkotással találkozunk, ahol a baromfi fö motívuma a festménynek vagy a grafikának. A következőkben kizárólag magyar, és közülük is csak néhány somogyi kötődésű művész alkotására szeretném felhívni a figyelmet, noha az egyetemes és a

20 A szobor felirata: „Non novi illum” - ... nem ismerem őt. (Luk. 22:57)

21 Michelangelo Merisi da Caravaggio (1571-1610) 
magyar művészek korábban közölt listáján olyan nevek szerepelnek, mint Bosch, Goya, Monet, Picasso, Chagall vagy Feszty, Ferenczy, Berény, Deák-Ébner és mások, akiket lenyügözött, s ez által megihletett valamelyik baromfi látványa. A sort Rippl-Rónai József nyitja, aki akár a Róma-villában megélt, akár a somogyaszalói vagy a somogytúri élményeit életképszerüen örökítette meg, számtalan alkotása árulkodik arról, hogy a baromfi ott volt, és fontos szerepet játszott a művész és környezte életében (29. és 30. ábra).

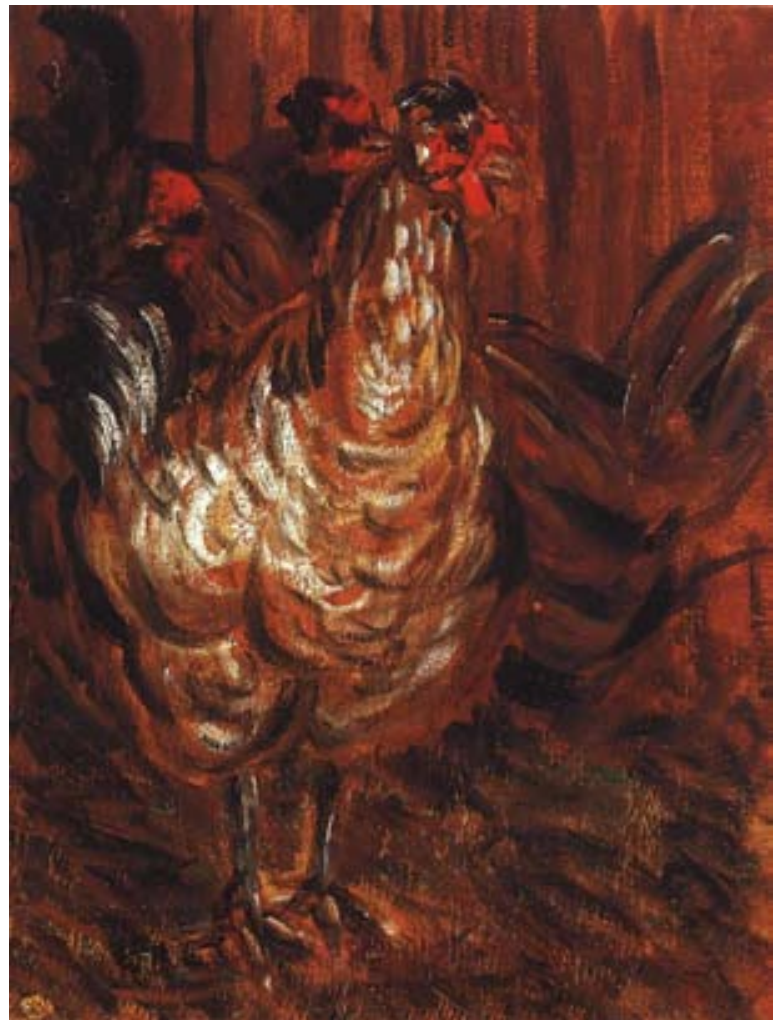

29. ábra. RIPPL-RÓNAI JÓZSEF (1861-1927): Kakas és tyúkok (1893-94)

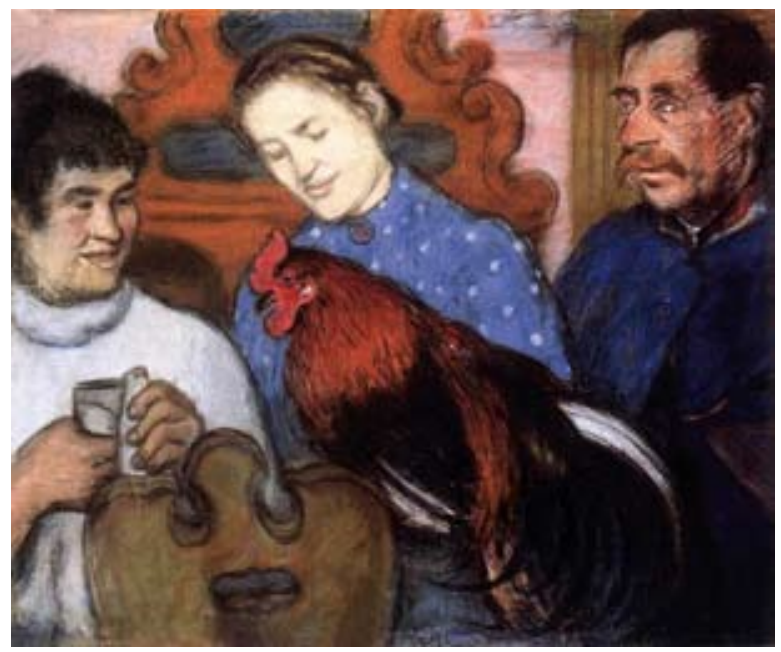

30. ábra. RIPPL-RÓNAI JÓZSEF (1861-1927): Az öreg ör és a kakas (1898-1902)
Úgy tűnik, hogy ezzel a dologgal a művészbarát Kunffy Lajos sem volt másként, mert a vidéki élet hétköznapi történései az ő alkotásairól is visszaköszönnek (31. ábra), de a téma követői között ott találjuk Vaszary Jánost és Rippl-Rónai tanítványát (32. ábra) a rokon Martyn Ferencet (33. ábra). A Kunffy által rajzolt pasztellnél érdemes egy pillanatra elidőzni. A jogász végzettségü müvésznek - és Párizsban kultúrdiplomatának - több mint 1100 holdas mintagazdasága volt Somogytúron és annak határában. A kép 1949-ben készült, amikor a parlagi tyúk mellett a magyar nemesített tyúk különböző színváltozatai - sárga, fehér, kendermagos, fogoly színü - már széles körben megtalálhatóak voltak a magyar vidéken, de utóbbinak nincs fekete változata. A fekete tollszín egyébiránt nem ritka a baromfitenyésztésben, de a képen látható kotlósnak fehér színű füllebenye van, tehát ez a fajta mészfehér tojásokat tojt, ami viszont szokatlan. Nagy valószínűséggel, ahogy Kunffy a gazdálkodás más területein igazi mintagazdaságot tartott fenn, a baromfi esetében is igényesen választotta meg a ház körüli nemesített fajtákat.

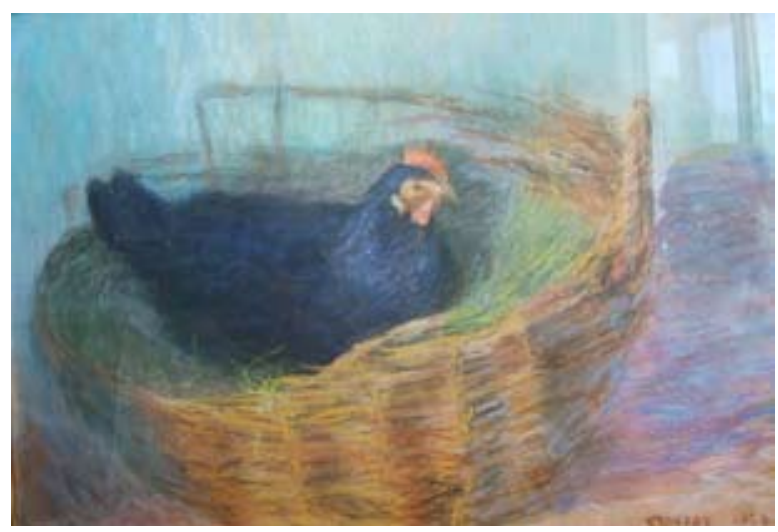

31. ábra. KUNFFY LAJOS (1869-1962):

Fekete tyúk kosárban (1949, Rippl-Rónai József Múzeum, Kaposvár)

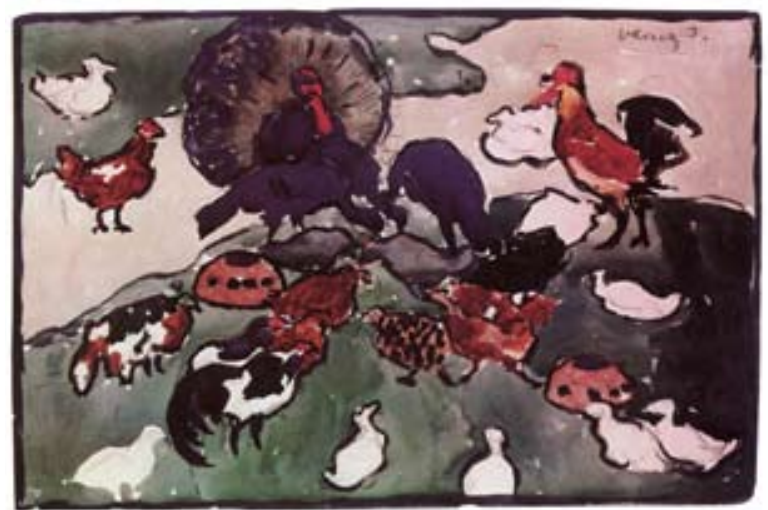

32. ábra. VASZARY JÁNOS (1867-1939):

Baromfiudvar - gobleinterv (1904 körül, Magyar Nemzeti Galéria, Budapest) 


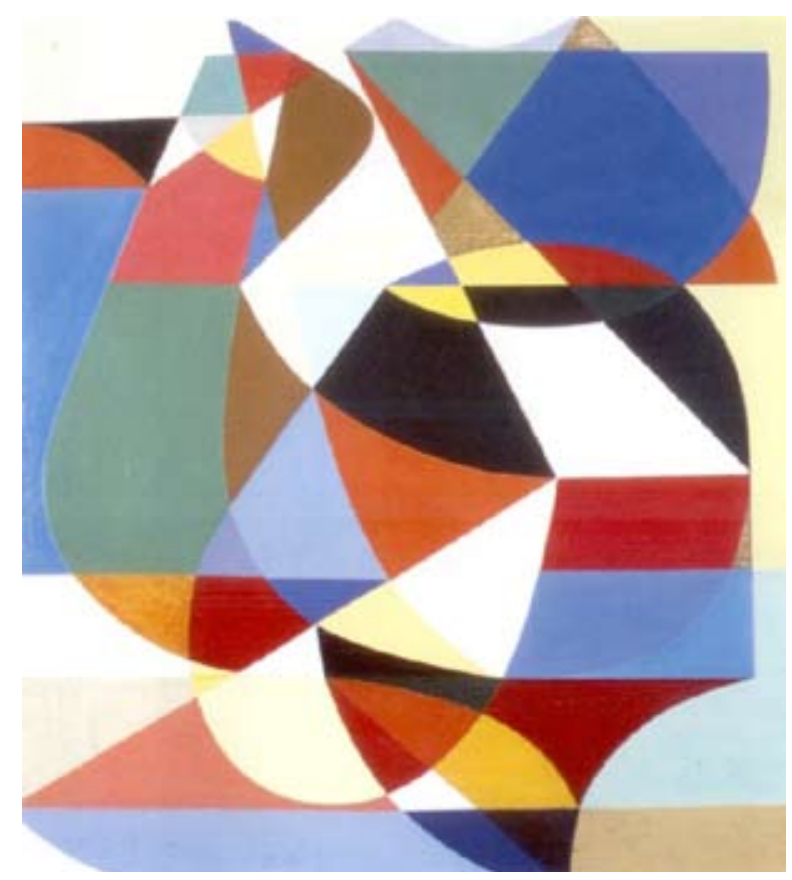

33. ábra. MARTYN FERENC (1899-1986): Kakas (1904)

És végezetül - bár a művész munkásságának nincsenek somogyi vonatkozásai, de - jöjjön az utolsó kép. Erről a festményröl nekem az jut eszembe, hogyha valaki lenyügöző módon ábrázolt házi szárnyasokban akar gyönyörködni, akkor néhány pillanatra időzzön el egy kicsit Vastagh Géza Kakas tyúkokkal című festmény előtt (34. ábra). Úgy gondolom, hogy az

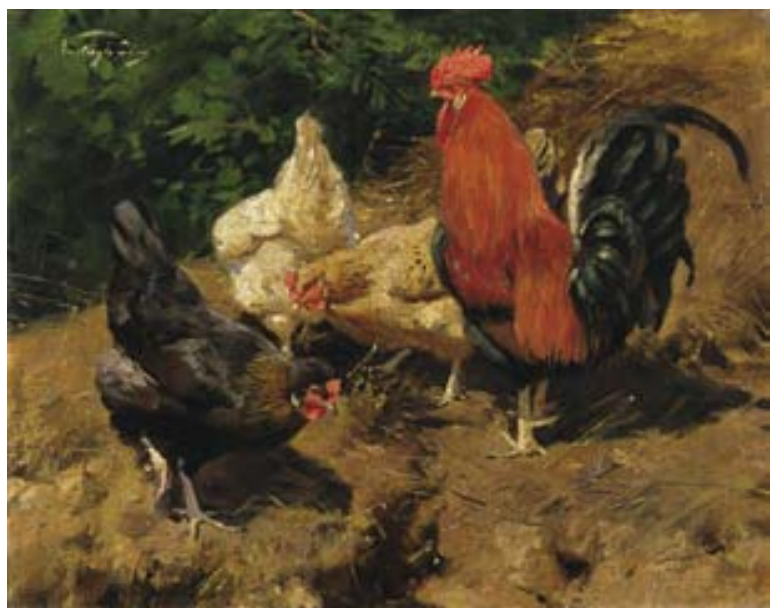

34. ábra. VASTAGH GÉZA (1866-1919): Kakas tyúkokkal

oktatás meglehetösen bonyolult rendszerében a képtárak mélyén fellelhető esztétikai élmény megidézésének a tananyag illusztrálásán túl az lenne a célja, hogy majd az agrártermelést irányító mérnökjelöltek meglássák a szépséget abban, amit csinálnak. Mert ha az ember a saját tevékenységében látja a szépet, akkor az szerethetö, amit pedig szeretve csinál, az örömet okoz, az örömmel végzett munka hatékonyságával pedig semmi nem tud versenyezni. A konkrét példához visszakanyarodva, ha mindez képes közvetíteni állattenyésztési müveltséget, érinti a hagyományainkat és szemléletet nyújt, akkor talán sikerült valamit az Általános állattenyésztés szerzőjétől tanulni és remélhetőleg továbbadni.

\section{Irodalom}

Bavarian State Picture Collection, Alte Pinakothek Munich, Explanatory notes on the works exhibited (Official Guide). Bayerische Staatsgemäldesammlungen Munich 1986 pp. 1-638. Ed. Lipp - Karl M. Lipp Verlag. Munich.

BARKócZI I. - CONTINI, R. - FusENIG, T. - Kovács Z. - PosAdA Kubissa, T. - LANGe, J. - Lermer, A. - Álvarez Lopera, J. Mal, E. - MARX, H. - NÉmeth I. - Nyerges É. - Roldán, D. - Portús, J. - Schütz, K. - Siefert, H. - Weniger, M. 2006: El Greco, Velázquez, Goya Öt évszázad spanyol festészetének remekmüvei. A Szépművészeti Múzeum Centenáriumi éve 2005. december 1. - 2006. december 1. Katalógus, p. 1-323. Kiadja: Szépmüvészeti Múzeum, Budapest.

BREHM, A. 1902-04: Az állatok világa. (Madarak IV., V., VI. kötet) Légrády Testvére, Budapest.

ENSMINGER, M. E. 1980: Poultry Science. (Animal Agriculture Series) The Interstate Printers \& Publishers, Inc., Danville, Illinois.

FARKAS Zs. (Szerk.) 2011: Rippl-Rónai József, Válogatás az AntalLusztig Gyüjteményből. Kiadó: Vaszary Képtár, Kaposvár.

GombRICH, E. H. 1972: The story of art. $12^{\text {th }}$ Ed. Phaidon Press Ltd. Hun. translation (1974): A müvészet története. Gondolat, Budapest.

Gundel J. 2013: Pulyka a gasztronómiában. A Baromfi Termék Tanács és a Magyar Pulykaszövetség közös „Hála az egészségnek - pulykaadás szakmai szemmel" c. szakmai rendezvény, 2013. november 28., Paulay Terem, Budapest.
HoRVÁTH J. ca. 2007: Kunffy Lajos. p. 1-176. Kiadja a Somogy Megyei Múzeumok Igazgatósága, Kaposvár.

HoRvÁTH J. (Szerk.) 2011: Rippl-Rónai 150'. p. 1-257. 150 éve született Rippl-Rónai József, Emlékkiállitás, 2011. augusztus 13december 31. Kiadó: „AGÓRA” Együd Árpád Kulturális Központ, Kaposvár.

ScIRÉ, G. N. 2005: The Accademia Galleries in Venice. p. 1-254. Mondadori Electa S.p.A., Milan.

StUNKENBROCK, C., TÖPPER, B. 1999: 1000 Meisterwerke der europäishen Malerei. h.f. ullmann publishing $\mathrm{GmbH}$., Hun. translation (2012): 1000 mestermü, európai festészet 1300-tól 1850-ig. Vince Kiadó, Budapest.

SzEnt BibliA (ford.: Károli G.) 2001: Magyar Bibliatársulat, Budapest.

\section{További források}

https://www.churchillcentral.com/quotes

http://www.express.co.uk/news/history/547792/Churchill-sanityhobby-saved [Warren, J.: Painting: The hobby that saved Winston Churchill's sanity. Express, Home of the Daily and Sunday Express, PUBLISHED: 08:43, Fri, Dec 19, 2014]

https://specialcollections.nal.usda.gov/guide-collections/worldspoultry-science-association-wpsa-records 
1. táblázat. Az egyetemes festömüvészet alakjai, akik alkotásain fö- vagy mellékmotívumként tyúk, pulyka vagy tojás ábrázolás található

1. Aertsen, Pieter (1508-1575)

2. Bassano, Jacopo (c.1515-1592)

3. Bassano, Francesco (1549-1592)

4. Bassano, Leonardo (1557-1622)

5. Bassano, Gerolamo (1566-1621)

6. Bloot, Pieter de (1601-1658)

7. Bloch, Carl Heinrich (1834-1890)

8. Bosch, Hieronymus (1450-1516)

9. Brandi, Domenico (1683-1736)

10. Brueghel, id. Jan (1568-1625)

11. Brueghel, ifj. Jan (1601-1678)

12. Bueckelaer, Joachim (1530-1574)

13. Campi, Vincenzo (1536-1591)

14. Caravaggio (M. Merisi) (1571-1610)

15. Cassana, Giovanni Agostino (1658-1720)

16. Commodi, Andrea (1560-1638)

17. Crivelli (Crivellone), Angelo Maria (?-1760)

18. Cuyp, Aelbert Jacobszoon (1620-1691)

19. Ceruti, Giacomo (1698-1767)

20. Cézanne, Paul (1839-1906)

21. Chagall, Marc (1887-1985)

22. Chardin, Jean-Baptiste Siméon (1699-1779)

23. Claesz, Pieter (1597/98-1661)

24. Crivelli (Crivellone), Angelo-Maria (1703-1730)

25. Eberle, Adolf (1843-1914)

26. Fyt, Jan (1611-1661)

27. Giaquerio, Giacomo (XV. sz.)

28. Dali, Salvador (1904-1989)

29. De Caro, Baldassare de (1689-1750)

30. Desportes, Alexandre-François (1661-1743)

31. Duccio, di Buoninsegna (1255/1260-1318/1319)

32. Empoli, Jacopo da (1551-1640)

33. Gérôme, Jean-Léon (1824-1904)

34. Goya, Francisco José de (1746-1828)

35. Goltzius, Hendrick (1558-1617)

36. Greuze, Jean-Baptiste (1725-1805)

37. Hamilton, Philipp-Ferdinand de (c.1664-1750)

38. Hermann, Werner (1816-1905)
39. Hondecoeter, Melchior d' (1636-1695)

40. Hondecoeter, Gillis Claesz d' (c.1575/80-1638)

41. Hunt, Edgar (1876-1953)

42. Jordaens, Jacob (1593-1678)

43. Kessel, id. Jan van II. (1626-1679)

44. Kessel, ifj. Jan van III. (1654-1708)

45. Kokoschka, Oskar (1886-1980)

46. König, Johann (1586-1642)

47. La Tour, Georges de (1593-1652)

48. Manet, Éduard (1832-1883)

49. Massys, Quentin (Quinten Matsijs) (1466-1530)

50. Meléndez, Luis Egidio (1716-1780)

51. Metsu, Gabriel (1629-1667)

52. Monet, Claude-Oscar (1840-1926)

53. Murillo, Bartolomé Esteban (1618-1682)

54. Paudiss, Christopher (ca. 1625-1666)

55. Picasso, Pablo (1881-1973)

56. Rijck, Pieter Cornelisz van (1567-c.1637)

57. Rijck, Cornelia de (1653-1726)

58. Ryck, Cornelia de (1656-?)

59. Rubens, Peter Paul (1577-1640)

60. Ruysdael, Salomon Van (1600/02-1670)

61. Savery, Roelandt (1576-1639)

62. Schouten, Henry (1857/64-1927)

63. Schouten Paul (1860-1922)

64. Snyders, Frans (1579-1657)

65. Stalbemt, Adriaen Van (1580-1662)

66. Steen, Jan Havickszoon (c. 1626-1679)

67. Tintoretto, Jacopo (1518-1594)

68. Tiziano, Vecellio (1477/1485-1576)

69. van Utrecht, Adriaen (1599-1652)

70. Velázquez, Diego Rodriguez (1599-1660)

71. Villach, Thomas von (c.1435/1440-c.1523/1529)

72. Vos, Paul de (c.1596-1678)

73. Weenix, Jan (1640-1719)

74. Wenzel, Peter (1745-1829)

75. Wtewael, Joachim (1566-1638)

76. Zoffany (Zauffaly), Johannes Josephus (1733-1810) 
2. táblázat. A magyar festészet kiválóságai, akik alkotásain fö- vagy mellékmotívumként tyúk, pulyka vagy tojás ábrázolás látható

1. Berény Róbert (1887-1953)

2. Bernáth Aurél (1895-1982)

3. Bogdány Jakab (c.1660-1724)

4. Bruck Lajos (1846-1910)

5. Deák-Ébner Lajos (1850-1934)

6. $\quad$ Egry József (1883-1951)

7. Ferenczy Károly (1862-1917)

8. Feszty Árpád (1856-1914)

9. Gyárfás Jenő (1857-1925)

10. Heyer Artúr (1872-1931)

11. Jakabfalvi mester (XV. sz.)

12. Koszta József (1861-1949)

13. Kunffy Lajos (1869-1962)
14. Martyn Ferenc (1899-1986)

15. Mersits Piroska (1926-1988)

16. Mészöly Géza (1844-1887)

17. Nagy Sándor (1869-1950)

18. Nagy Sándor János (1897-1952)

19. Neuhauser Ferenc (1763-1836)

20. Pataky László (1857-1912)

21. Pálinkás Béla (1880-?)

22. Pállik Béla (1845-1908)

23. Rippl-Rónai József (1861-1927)

24. Stranover Tóbiás (1684-1756)

25. Vastagh Géza (1866-1919)

26. Vaszary János (1867-1939) 